\title{
Tax Compliance Test Before And After It Does Tax Amnesty In Kanwil Djp Bali
}

\author{
Ida I Dewa Ayu Mas Manik Sastri, Luh Kade Datrini, Ni Nyoman Rusmiati \\ \{info@warmadewa.ac.id\} \\ Universitas Warmadewa, Denpasar, Bali
}

\begin{abstract}
The implementation of the tax amnesty from July 2016 to March 2017 has stimulated the growth of state revenues. At the DGT Bali, the number of corporate taxpayers and individuals participating in the tax amnesty were 31,747. According to Statement of Assets (SPH), the overall assets amnesty was valued at Rp. 63,219.15 billion. The total payment received by the Bali DGT Regional Office during the tax amnesty period was Rp. 1,189.58 billion. The purpose of this study is to determine the empirical evidence of the differences in taxpayer compliance before and after the passing of the tax amnesty at the Bali DGT Regional Office. The sampling technique used was saturated. The number of samples used was 715,972 taxpayers before the implementation of the amnesty. This is the number of registered individuals from April to June 2015 and 2016. The number of taxpayer for a period after the amnesty was 771,274. These are the registered people from April 2017 to June 2018. Testing the compliance of Taxpayers before and after unsettled tax amnesty used two different Test average, or the Paired Sample T-Test. The results of the study show that there is no significant effect on the number of additional taxpayers and the tax revenue before and after the amnesty is implemented.
\end{abstract}

Keywords: Tax, Taxpayer, Tax Amnesty

\section{Introduction}

On 1 July 2016, the Government established Law No. 11 of 2016 concerning Tax Amnesty. This law has been postponed several times, after robust discussions in the DPR since 2015. The failure to achieve tax revenues over the past few years has triggered the enactment of this law after the government saw that tax revenues were still low due to a lack of public awareness in reporting taxes even though the government in the last few years has relied heavily on state revenues from tax revenues. The implementation of the tax amnesty during the period of July 2016 to March 2017 has provided a stimulus for the growth of state revenues. It was recorded at the DGT Bali that the number of corporate taxpayers and individuals who participated in amnesty were 31,747 Statement of Assets (SPH), with the total assets valued at Rp. 63,219.15 billion. The total amount of ransom received by the Bali DGT Regional Office during the amnesty period was IDR 1,189.58 billion. The things that should be considered in tax receipts are the low realization of tax revenue or tax ratio in Indonesia and low level of tax compliance.Note the World Bank, recorded Indonesia's tax ratio during 
2014 was only $10.84 \%$ of Gross Domestic Gross, while the average tax ratio of countries in the world was $14.81 \%$. Thus, the level of tax collectibility in Indonesia is still minimal, so it is quite heavy in supporting state spending. Even compared to neighboring countries, Indonesia is still smaller. For example, Malaysia (14.8\%), Singapore (13.9\%), Philippines (13.6\%), Thailand (16\%) and Cambodia (14.6\%). In Indonesia, tax revenues have a portion of $86.26 \%$ of the total state revenue or Rp. 1,539 trillion from 1,784 trillion. This encouraged the need for several breakthroughs for the government to encourage increased tax revenues. Latest related research of [1] Economic Analysis Tax Amnesty in Russia found that Tax Amnesty in Russia had no positive or negative effect on the increase in Russian income. Whereas [2] found two concerns from a tax amnesty, the first was expected to increase tax system fraud and inefficiency and secondly it was possible to give birth to people who cheated on tax evasion through Tax amnesty. This research is a continuation of two previous studies, the first study in 2016 about the factors that influence corporate taxpayer compliance in East Denpasar KPP, by taking two independent variables namely taxation socialization and DGT service quality while the dependent variable is corporate taxpayer compliance. The second study in 2017 was continued regarding the implementation of the tax amnesty from July 2016 to March 2017, with the title DGT's efforts to increase post-amnesty tax revenues, from the FGD results found 4 variables that DGT must do in an effort to increase post-amnesty tax revenues, namely Information Disclosure between institutions, Examination and pengahahiran IT systems and tax data information. After testing with multiple linear regression found two variables, namely tax audit, and information disclosure between institutions that must be intensified by the DGT. The aim of this study is to obtain empirical evidence of differences in taxpayer compliance, before and after the holding of a tax amnesty at the Bali DGT Regional Office. Therefore, the output of this study is to provide policy guidance to the Regional Office of the Directorate General of Taxes in making efforts to improve taxpayer compliance, which will be published in the local journal ISBN Krisna: Kumpulan Riset Akuntansi, Accounting Department, Universitas Warmadewa.

\section{Literature Reviw}

\subsection{Taxpayer Compliance}

Compliance is a function of sanctions, most of the behavior can be predicted when we know the rules of the game [3]. Tax Compliance (tax compliance) relates to activities to comply with tax rules, which include: administration, bookkeeping, tax deductions, deposits, reporting, etc. [4]. The criteria for compliant taxpayers according to the Decree of the Minister of Finance Number 192 / PMK.03 / 2007 include:

1. Obedient Taxpayer, Compliant taxpayers are taxpayers who meet the following requirements:

a. Timely in delivering notice.

b. Has no tax arrears for all types of taxes, except tax arrears that have obtained permission to pay in installments or delay payment of taxes.

c. Financial statements are audited by Public Accountants or government financial supervision institutions with unqualified opinions for 3 (three) consecutive years.

d. Never been convicted of committing a criminal offense in the field of taxation based on a court decision that has permanent legal force within the last 5 (five) years.

1. On time, Timely delivery of Notification (SPT) includes. 
a. Submission of Annual Notification on time in the last 3 (three) years.

b. Submission of Notification Periods that are late in the previous year for the period January to November not more than 3 (three) Tax Periods for each type of tax and not consecutively.

c. Notification of the period as late as referred to in number 2 has been submitted not later than the deadline for submission of the following Tax Period Notice.

In taxation, the rule that applies is the Taxation Law. Taxpayer compliance is a person's compliance with tax regulations or laws. Taxpayer compliance is the fulfillment of obligations carried out by taxpayers to contribute to the development of the country which is expected to be carried out voluntarily. Taxpayer compliance is an important aspect considering that the taxation system in Indonesia adheres to the self-assessment system wherein the process gives trust to the Taxpayers to calculate, pay and report their obligations. The causes of noncompliant taxpayers vary because the main thing is the income obtained by the primary taxpayer aimed at fulfilling his life needs. The emergence of conflict between self-interest and the interests of the state. Another reason is that taxpayers are less aware of state obligations, are not obedient to the rules and do not respect the law, high tax rates, and environmental conditions.

\subsection{Tax of Amnesty}

Tax amnesty is the tax payable should be a deletion, not prosecuted the administration of taxation and criminal sanctions in the field of taxation, by way of uncovering treasure and paid the ransom as outlined in the Act. Tax amnesty aims to:

1. Accelerate the growth and economic restructuring through the transfer of wealth, among others, will have an impact on improving domestic liquidity, elevated exchange rate of Indonesian rupiah, decreasing interest rates, and increased investment

2. Push the tax reform toward a more equitable tax system as well as the expansion of the database of taxation is more valid, comprehensive and integrity

3. Increase tax revenues to be used for the financing of development.

\subsection{Hypotheses}

Tax amnesty (remission of taxes) is the Elimination of tax payable, that should not incur sanctions the administration of taxation and criminal penalties in the field of taxation, by way of uncovering treasure and paid the ransom as outlined in the Act. Based on theory and previous research results then the hypothesis presented in this study are: there is a difference of compliance taxpayers before and after doing a tax amnesty.

The object of research was conducted in the territory of the regional X_ROBINFAN_X Bali with object research test compliance taxpayers before and after doing a tax amnesty in the regional X_ROBINFAN_X Bali. Population research is the taxpayer listed on the regional X_ROBINFAN_X Bali totaling 771,274 taxpayers. The sample is part of the number and characteristics of which are owned by the population. Method of determination of the sample the sampling technique used was saturated is the technique of independence of the example when all members of a society are used as a sample [5].

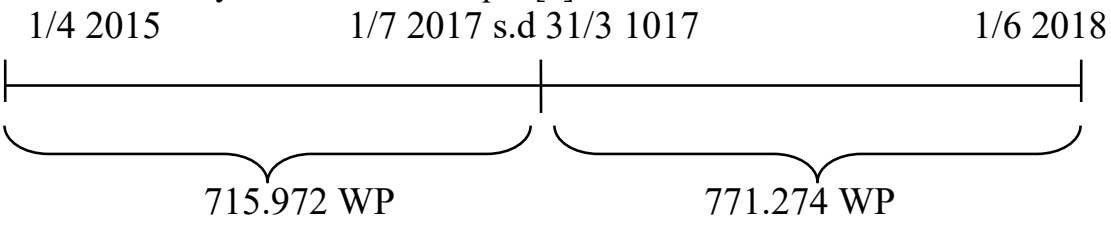


Images 1. Method of Research The number of Samples used in the study

The number of samples used in the study was 715,972 the taxpayer for a period before the implementation of a tax amnesty that is the number of registered Taxpayers from April until June 2015 and 2016771,274 the taxpayer for a period after the application of the a tax amnesty that is the number of registered Taxpayers from April 2017 until June 2018. The research, which are the variables of variables in this research is taxpayer compliance. Operational definitions of variables, taxpayer Compliance, is a function of the sanctions, most predictable behavior when we know the rules of the game [3]. Tax Compliance (tax compliance) associated with activities to comply with tax rules, which include: administrative, bookkeeping, tax cutting/collection, remittance, reporting, and so forth [4]. Testing the compliance of Taxpayers before and after unsettled tax amnesty used two different Test average (Paired Sample T-Test). Paired Sample T-Test or a paired samples t-test aimed at testing the average difference of two related samples [6]. This test can be performed on the subject before and after a process. Testing conducted with a level of significance of 0.05 and degrees of freedom $(\mathrm{df})=\mathrm{N}-1$. The formulation of hypotheses in this test are as follows:

HO: there are no Taxpayer compliance differences before and after the performance of tax amnesty.

HA: there is a difference of compliance Taxpayers before and after the performance of a tax amnesty.

Based on the formulation of a hypothesis, the taking of the decision is as follows:

a. If significance $>0.05$, then Ho accepted and Ha was rejected.

b. If the significance of $\leq 0.05$, then Ho denied and Ha is received.

\section{Result And Discussion}

\section{1 Description of Data}

The object of this research is the level of compliance by taxpayers at the Regional Office oversees several Balinese X_ROBINFAN_X KPP Pratama and Madya KPP. Implementation of Tax Amnesty based on law No. 11 The year 2016 about forgiveness of taxes assigned 1 July 2016 where its implementation starts from July 2016 until March 2017. The variables used in this study, i.e., the compliance rate Taxpayers before and after the performance of a tax amnesty. Measurement of the level of compliance of Taxpayers divided into two proxy, among other things: The amount of the tax receipt at the regional X_ROBINFAN_X Bali, compare the amount of tax revenue before and after the implementation of Tax Amnesty on X_ROBINFAN_X Regional Bali, namely: Total tax revenues before tax amnesty unsettled NOOBS UNITED during the 15 months that is starting from the April 2015 until June 2016 times.

Table 1. Tax Receipt Data Before He Did No Amnesty

\begin{tabular}{ccc}
\hline \multicolumn{3}{c}{ NOOBS UNITED Regional Bali (In Rupiah) } \\
No & Tax Time & Number of Admissions \\
\hline 1 & April 2015 & 664.176 .783 .598 \\
2 & Mei 2015 & 538.682 .306 .924 \\
3 & Juni 2015 & 562.889 .807 .902 \\
4 & Juli 2015 & 600.052 .970 .209 \\
5 & Agustus 2015 & 562.177 .696 .492 \\
6 & September 2015 & 570.026 .285 .430 \\
\hline
\end{tabular}




\begin{tabular}{ccc}
\multicolumn{3}{c}{ NOOBS UNITED Regional Bali (In Rupiah) } \\
No & Tax Time & Number of Admissions \\
\cline { 2 - 4 } 7 & Oktober 2015 & 614.939 .266 .169 \\
8 & Nopember 2015 & 665.323 .197 .331 \\
9 & Desember 2015 & 1.334 .357 .076 .010 \\
10 & Januari 2016 & 546.413 .549 .542 \\
11 & FebruARI 2016 & 460.890 .492 .405 \\
12 & Maret 2016 & 524.948 .935 .076 \\
13 & April 2016 & 639.624 .468 .344 \\
14 & Mei 2016 & 578.414 .380 .262 \\
15 & Juni 2016 & 737.424 .702 .057 \\
& Jumlah & 9.600 .341 .917 .751 \\
\hline \multicolumn{3}{c}{}
\end{tabular}

Source: Kanwil DJP Bali

Based on table 2, the number of known Regional acceptance X_ROBINFAN_X Bali for 15 months from the April to June Period up to 20152016 (before unsettled tax amnesty) is amounting to $\operatorname{Rp} 9,600,341,917,751$

Table 2. Tax Receipt Data After He Did No Amnesty

\begin{tabular}{ccc}
\hline & \multicolumn{2}{c}{ Kanwil DJP Bali (In Rupiah) } \\
No & Tax Time & Number of Admissions \\
\hline 1 & April 2017 & 631.336 .123 .299 \\
2 & Mei 2017 & 614.281 .115 .169 \\
3 & Juni 2017 & 612.816 .445 .295 \\
4 & Juli 2017 & 690.060 .307 .536 \\
5 & Agustus 2017 & 673.891 .374 .776 \\
6 & September 2017 & 648.994 .315 .060 \\
7 & Oktober 2017 & 717.770 .128 .771 \\
8 & Nopember 2017 & 745.424 .262 .827 \\
9 & Desember 2017 & 1.065 .852 .114 .637 \\
10 & Januari 2018 & 680.644 .184 .729 \\
11 & Februari 2018 & 489.823 .967 .842 \\
12 & Maret 2018 & 684.506 .601 .150 \\
13 & April 2018 & 917.747 .855 .258 \\
14 & Mei 2018 & 752.793 .551 .696 \\
15 & Juni 2018 & 674.110 .880 .984 \\
& Jumlah & 10.600 .053 .229 .029 \\
\hline
\end{tabular}

Source: Kanwil DJP Bali

Based on table 3 can be known the amount of tax revenue after the tackle in a tax amnesty for 15 months calculated from the period of April to June period up to $20172018 \mathrm{Rp}$ $10,600,053,229,029$

The number of additional taxpayers registered

Compare the number of registered taxpayers additions before and after implementation of Tax Amnesty on X_ROBINFAN_X Regional Bali, namely: Additional taxpayers registered on X_ROBINFAN_X Bali to tackle before the tax amnesty for 15 months, i.e., April 2015 Period ranging from up to the time of June 2016.

Table 3. After the Performance of Tax Amnesty

\begin{tabular}{ccc}
\hline & Kanwil DJP Bali & \\
No & Month & Additional Tax Payers \\
\hline 1 & April 2015 & 4.662 \\
\hline
\end{tabular}




\begin{tabular}{ccc}
\hline \multicolumn{3}{c}{ Kanwil DJP Bali } \\
No & Month & Additional Tax Payers \\
\hline 2 & Mei 2015 & 4.024 \\
3 & Juni 2015 & 4.109 \\
4 & Juli 2015 & 2.462 \\
5 & Agustus 2015 & 3.514 \\
6 & September 2015 & 3.515 \\
7 & Oktober 2015 & 3.572 \\
8 & Nopember 2015 & 3.745 \\
9 & Desember 2015 & 3.143 \\
10 & Januari 2016 2016 & 3.874 \\
11 & FebruARI 2016 & 3.620 \\
12 & Maret 2016 & 4.052 \\
13 & April 2016 & 4.480 \\
14 & Mei 2016 & 3.888 \\
15 & Juni 2016 & 3.511 \\
& An Additional Amount The Taxpayer & 56.171 \\
\hline
\end{tabular}

Source Kanwil DJP Bali

Based on table 4, it can be known the number of additional taxpayers during the April to June Period up to 20152016 as much 56,171 taxpayers and private bodies.

Table 4. Data addition of Taxpayers Registered After he did No Amnesty

\begin{tabular}{ccc}
\hline \multicolumn{3}{c}{ Kanwil DJP Bali } \\
No & Month & Additional Tax Payers \\
\hline 1 & April 2017 & 2.840 \\
2 & Mei 2017 & 3.702 \\
3 & Juni 2017 & 3.161 \\
4 & Juli 2017 & 4.691 \\
5 & Agustus 2017 & 3.802 \\
6 & September 2017 & 3.134 \\
7 & Oktober 2017 & 3.536 \\
8 & Nopember 2017 & 3.567 \\
9 & Desember 2017 & 3.136 \\
10 & Januari 2018 & 4.339 \\
11 & Februari 2018 & 4.723 \\
12 & Maret 2018 & 4.119 \\
13 & April 2018 & 4.354 \\
14 & Mei 2018 & 3.717 \\
15 & Juni 2018 & 2.481 \\
& Amount & 55.302 \\
\hline
\end{tabular}

Based on table 5, knowable number of additional taxpayers after the unsettled tax amnesty period April 2017 tax up to June 2018 as much taxpayer 55,302 bodies and private persons

\subsection{Data analysis}

Testing the compliance of Taxpayers before and after the tax amnesty used Two Different Test average (Paired Sample T-Test). Paired Sample T-Test or a paired samples t-test aimed at testing the average difference of two related samples [6]. This test can be performed on the subject before and after a process. Testing conducted with a level of significance of 0.05 and degrees of freedom (df) N-1. Following is the result of testing paired sample t-test compliance taxpayers before and after the Tax Amnesty on the regional Bali NOOBS UNITED 


\subsection{Test of Paired Samples Statistics}

Table 5. Paired Samples Test Result Statistics Tax Receipt

\begin{tabular}{ccccc}
\hline & Mean & $\mathrm{N}$ & Std. Deviation & Std. Error Mean \\
\hline Pair 1 Tax revenues before Tax & 640.029 .933 .333 & 15 & 203.559 .290 .236 & 52.558 .782 .736 \\
Amnesty & & & & \\
Tax revenue after the Tax Amnesty & 706.670 .000 .000 & 15 & 134.765 .382 .352 & 34.796 .272 .099 \\
\hline Source: Processed Data (Lampiran 5) & & & &
\end{tabular}

Based on the results of the test statistic in table 7 , then the test results can be explained tax revenue before and after the implementation of the Tax amnesty. Tax revenues prior to the implementation of tax amnesty are $\mathrm{Rp} 640,029,933,333$ while tax revenues after the implementation of the tax amnesty is $\mathrm{Rp} 706,670,000,000$. This shows that tax revenue has increased after the implementation of the tax amnesty.

Tabel 6. Paired Samples Test Result Statistics The Addition of The Number of Taxpayers

\begin{tabular}{lcccc}
\hline & Mean & N & $\begin{array}{c}\text { Std. } \\
\text { Deviation }\end{array}$ & $\begin{array}{c}\text { Std. Error } \\
\text { Mean }\end{array}$ \\
\hline $\begin{array}{c}\text { Pair 1 The addition of the Tax Amnesty before the } \\
\text { addition of WP WP after a Tax Amnesty }\end{array}$ & 3744,7333 & 15 & 530,35385 & 136,93678 \\
& & & & \\
& 3686,8000 & 15 & 668,01467 & 172,48065 \\
\hline
\end{tabular}

Source: Processed Data (Lampiran 5 lanjutan)

Based on the results of the test statistic in table 7, then it can test effects described the addition of the number of Taxpayers before and after the Tax Amnesty. The addition of the number of Taxpayers before the implementation of tax amnesty is 3,744 Taxpayers. While the addition of the number of Taxpayers after the application of tax amnesty of 3,686 Taxpayers. This shows that the addition of the number of Taxpayers has decreased after the implementation of the tax amnesty.

\subsection{Paired Sample Test}

Tabel 7. Test Results Paired Sample Test Tax Receipt

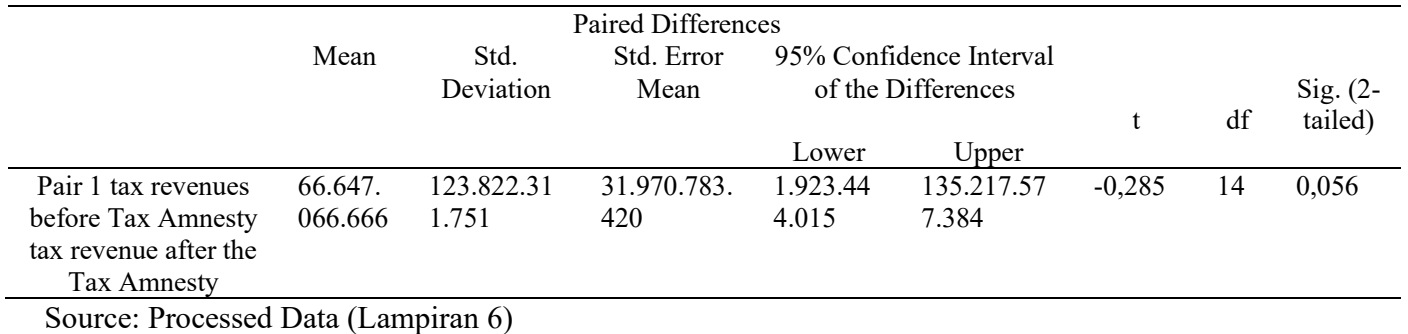

Based on Table 9 test results, tax revenue before and after the implementation of tax amnesty shows Sig (2-tailed) of 0.056 which is higher than the value of the probability of 0.05 . From the test results then Ho received, or there is no significant difference in tax revenue before and after the implementation of the tax amnesty. 
Table 8 Test Results Paired Sample Test The addition of the number of Taxpayers

\begin{tabular}{|c|c|c|c|c|c|c|c|c|}
\hline & \multicolumn{5}{|c|}{ Paired Differences } & \multirow{2}{*}{$\mathrm{t}$} & \multirow[t]{2}{*}{$\mathrm{df}$} & \multirow{2}{*}{$\begin{array}{l}\text { Sig. (2- } \\
\text { tailed) }\end{array}$} \\
\hline & Mean & $\begin{array}{c}\text { Std. } \\
\text { Deviation }\end{array}$ & $\begin{array}{l}\text { Std. Error } \\
\text { Mean }\end{array}$ & $\begin{array}{r}95 \% \mathrm{C} \\
\text { Inter } \\
\text { Diff }\end{array}$ & $\begin{array}{l}\text { fidence } \\
\text { of the } \\
\text { nces }\end{array}$ & & & \\
\hline $\begin{array}{l}\text { Pair The addition of } \\
\text { the tax amnesty } \\
\text { before the addition } \\
\text { of WP } \\
\text { WP after tax } \\
\text { anmesty }\end{array}$ & $\begin{array}{l}57,933 \\
33\end{array}$ & $\begin{array}{c}927,5406 \\
4\end{array}$ & $\begin{array}{c}239,4899 \\
6\end{array}$ & $-455,722$ & $\begin{array}{c}571,5888 \\
22\end{array}$ & $-0,242$ & 14 & 0,812 \\
\hline
\end{tabular}

Based on Table 10, test results the addition of the number of Taxpayers before and after the implementation of PP No. 46 the Year 2013 shows Sig (2-tailed) of 0.812 which is higher than the value of the probability of 0.05 . From the test results then Ho received, or there is no significant difference the addition of the number of Taxpayers before and after implementation of tax amnesty.

\subsection{Discussion}

Based on the results of testing the amount of tax revenue and increased the number of Taxpayers using paired samples t-test test obtained the results that there was no significant difference between the amount of tax revenue and increased the number of Taxpayers before and after the implementation of the tax amnesty. Table 2 and table 3 show that tax revenue has increased after the implementation of the tax amnesty. Due to the increased tax revenue after the application of tax amnesty then increased Taxpayer compliance. The increase happened does not indicate the existence of significant differences In table 4 and table 5 shows that the addition of the taxpayer after implementation of tax amnesty are smaller compared to before the application of tax amnesty. The decline that occurred did not indicate the existence of a significant difference between the amount of tax revenue and increased the number of Taxpayers after the implementation of tax amnesty. Because not all Taxpayers impacted by a tax amnesty, even most of the Taxpayer listed on X_ROBINFAN_X Bali not affect the impact of the implementation of the tax amnesty.

The results of this study are in line with the results of research conducted by [7] aims to test the influence of tax forgiveness program (tax amnesty) against the effectiveness of acceptance taxes in Indonesia KPP. The source of the data in her research is secondary data in the form of tax revenue data KPP Se-Indonesia Years 2015 and 2016 Year. The samples used in research are tax revenues that come from $341 \mathrm{KPP}$. Data analysis techniques used there are two, i.e., the descriptive analysis and verification analysis. To test the hypothesis in his research used two different test samples associated (paired sample t-test). The results showed that the remission of tax (a tax amnesty) does not give significant effects against the effectiveness of tax revenue in the KPP Indonesia. Based on the results obtained from the efficacy of the KPP 341 admission taxes reach effective only won by 53 KPP (16\%) while most as much as $288 \mathrm{KPP} 84 \%$ of other or have not reached effectively. 


\section{Conclusion}

Based on the discussion that has been presented before, then obtained a summary that there was no significant difference in the level of compliance of taxpayers before and after implementation of tax amnesty on the regional Bali X_ROBINFAN_X seen from the growth of mandatory taxes are registered and receipt of taxes. From the data obtained and the results of the test sample paired t-tests that have been done. It is known that the number of tax revenues tends to experience increased after the implementation of tax amnesty, but the increase that occurred did not show the differences significant because based on the test results paired sample t-test there was no significant difference between the amount of tax revenue increased the number of Taxpayers before and after implementation of tax amnesty on X_ROBINFAN_X Bali. Value added the taxpayer thus experienced a decline after he did a tax amnesty, because not all of the Balinese people affected by a tax amnesty program initiated by the Government of Indonesia.

\section{References}

[1] J. Alm, "Do Tax Amnesty Work? The Revenue Effect of Tax Amnesty During the Transition the Rusia," 2009.

[2] J. Andreoni, "The desirability of permanent Tax Amnesty," J. Public Econ., 1991.

[3] I. Arfan, Perpajakan. Yogyakarta: BPFE UGM, 2014.

[4] C. Anwar, Perpajakan. Yogyakarta: Andi Offset, 2013.

[5] Sugiyono, Metode Penelitian Bisnis. Bandung: Alfabeta, 2013.

[6] I. Ghozali, Aplikasi Multivariate dengan Program SPSS. Semarang: Badan Penerbitan Universitas Diponegoro, 2013.

[7] O. Adam, H. Tuli, and S. P. Husain, "Pengaruh Program Pengampunan PajakTerhadap Efektivitas Penerimaan Pajak di Indonesia," J. ilmu Akunt. Univ. Gorontalo, 2017. 